\title{
The Effects of Ethanol Extract, Chayote (Sechium Edule (Jacq.) Swartz) Fraction and Juice on the High-density Lipoprotein Level in Male White Mice
}

\author{
Jekson Martiar Siahaan1,2), Endy Juli Anto3,4), Tengku Muhammad Fauzi5,6) \\ ${ }^{1)}$ Department of Physiology, Faculty of Medicine, Universitas Methodist Indonesia, Medan \\ ${ }^{2)}$ Department of Molecular Biology, Masters Program in Biomedical Sciences, \\ Faculty of Medicine, Universitas Methodist Indonesia, Medan \\ ${ }^{3)}$ Department of Parasitology, Faculty of Medicine, Universitas Methodist Indonesia, Medan \\ ${ }^{4)}$ Department of Immunology, Masters Program in Biomedical Sciences, \\ Faculty of Medicine, Universitas Methodist Indonesia, Medan \\ ${ }^{5)}$ Department of Histology, Faculty of Medicine, Universitas Methodist Indonesia, Medan \\ ${ }^{6)}$ Laboratorium Biomedical, Masters Program in Biomedical Sciences, Faculty of Medicine, \\ Universitas Methodist Indonesia, Medan
}

\section{ABSTRACT}

Background: Cholesterol imbalance occurs in Diabetes Mellitus, where high-density lipoprotein (HDL) levels are low and low-density lipoprotein (LDL) increases, where this imbalance results in the appearance of atherosclerosis. HDL has antiarterosclerotic potential so it needs to be targeted for therapy. One of the bioactive compounds that have this effect is found in chayote (Sechium edule (Jacq.) Swartz). This study aimed to examine the effects of ethanol extract, Chayote (Sechium Edule (Jacq.) Swartz) fraction and juice on the HDL level in male white mice

Subjects and Method: A randomized controlled trial study was conducted to test HDL level in 54 male white rats of the Wistar strain (Rattus novergius sp.) after received ethanol extract, Chayote (Sechium Edule (Jacq.) Swartz) fraction and juice. The dependent variable was the HDL level. The independent variable was the variation in the dose of ethanol extract, fraction and Sechium edule (Jacq.) Swartz Juice. The data were analyzed using Anova test.

Results: The treatment group induced by Streptozotocin $50 \mathrm{mg} / \mathrm{kgBW}+$ nicotinamide
$(120 \mathrm{mg} / \mathrm{kgBW})+\mathrm{HFD}$ and obtained ethanol extract of chayote fruit $150 \mathrm{mg} / \mathrm{kgBW}$, orally had the highest average HDL levels compared to other groups $($ Mean $=17.31 ; \mathrm{SD}=3.14)$.

Conclusion: The ethanol solvent found in the ethanol extract is better because it attracts biaoctive compounds so that it has a better effect than the ethyl acetate fraction and the nhexane fraction.

Conclusion: The ethanol solvent found in the ethanol extract is better because it attracts biaoctive compounds so that it has a better effect than the ethyl acetate fraction and the nhexane fraction.

Keywords: HDL, Flavonoid, Sechium edule (Jacq.) Swartz

\section{Correspondence:}

Jekson Martiar Siahaan. Department of Physiology, Faculty of Medicine, Universitas Methodist Indonesia. Jl. Setia Budi Pasar II Tj. Sari, Medan 20132, North Sumatera. Email: jekson.siahaan.sked@gmail.com.

\section{Cite this as:}

Siahaan JM, Anto EJ, Fauzi TM (2021). The Effects of Ethanol Extract, Chayote (Sechium Edule (Jacq.) Swartz) Fraction and Juice on the High-density lipoprotein Level in Male White Mice. Indones J Med. 06(02): 145-151. https://doi.org/10.26911/theijmed.2021.06.02.03.

cc) (i) (-) Indonesian Journal of Medicine is licensed under a Creative Commons cc. Ar No SA Attribution-NonCommercial-ShareAlike 4.0 International License. 


\section{BACKGROUND}

Diabetes mellitus (DM) is a risk factor for atherosclerosis which can lead to complications of heart disease. Atherosclerosis is caused by high blood fat low-density lipoprotein (LDL) while high-density lipoprotein (HDL) is low (Farbstein and Levy, 2012). Atherogenic dyslipidemia in diabetes is characterized by increased concentrations of TG-rich lipoproteins (TRLs), small dense Low Density Lipoproteins (sd-LDL), decreased HDL concentrations in serum (Hirano $\mathrm{T}, 2018$ ). In $\mathrm{DM}$, there are 2 important pathways that cause atherosclerosis, namely hyperglycemia and insulin resistance, secondly dyslipidemia. Both of these pathways will induce oxidative stress and inflammation which affects the endothelial dysfunction of blood vessels, which will then develop into atherosclerotic lesions (Poznyak et al., 2020).

HDL has an important role as antiatherogenic, carrying cholesterol from the periphery to the liver, anti-inflammatory by inhibiting TNF- $\alpha$ (tumor necrosis factor- $\alpha$ ) and IL-1 (interleukin 1) stimuli, antithrombotic, antiapoptotic, antioxidant, vasodilator, and repairing vessel endothelium, blood, glucose homeostasis (Barter, 2011; Farbstein and Levy, 2012; Younis and Durrington, 2012; Femlak et al., 2017). HDL dysfunction in DM occurs due to the state of insulin resistance inactivating lipolytic enzyme lipoprotein lipase (LPL) thereby reducing triglyceride hydrolysis (TG), cholesteryl ester transfer protein (CETP) induces HDL catabolism, and increased hepatic triglyceride lipase (HTGL) activity causes HDL clearance to also increase (Bjornstad and Eckel, 2018).

This reduction in HDL levels can be prevented by administering flavonoids including Isoflavones, anthocuanidins, flavanols, flavonols, flavones and flavanones. The mechanism of action is by increasing the activity of Paraoxonase 1 (PON1) by preventing modification of LDL and the main component of HDL antiarterosclerosis (Tavori et al., 2010; Millar et al., 2017). One of these flavonoids can be found in the Sechium edule (Jacq.) Swartz chayote. A study by Siahaan et al. (2019), shows that the flavonoids in chayote have antihypertriglyceride, antiobesity, antihyperglycemia and antioxidant effects. In addition, the polyphenol extract of the chayote root of Sechium edule (Jacq.) Swartz promoted lipogenesis and stimulated lipolysis by activating signal AMPactivating protein kinase (AMPK) on HepG2 cells (Wu, et al., 2014). Its biological effect is cardioprotective by increasing HDL and reducing VLDL, LDL, total cholesterol, triglycerides, serum transminase, alkaline phosphatase, lactate dehydrogenase, creatinine kinase (Vieira et al., 2018). In this study, the authors tried to examine the effectiveness of ethanol extract, fractions and Sechium edule (Jacq.) Swartz juice on HDL levels.

\section{SUBJECTS AND METHOD \\ 1. Study Design}

This study used a pure experimental research type with the post test method randomized controlled group design.

\section{Population and Sample}

The experimental animals used in this study were white male Wistar rats, aged 2.5 - 3 months, body weight $180-220$ grams and healthy. The selection of mice as experimental animals is based on the consideration that genetically, rats have similarities to humans and have the ability to adapt to the laboratory environment. The sample allocation (grouping) of experimental animals used simple random sampling. The sample size was estimated using Federer's formula, each group using 3 male white rats Wistar (Rattus novergius sp.) 
With 18 groups of treatment groups so that the total number of the study sample was 54. Chayote was done using purposive sampling method, which is taken from the yard of the Sidamanik residents.

\section{Study Variables}

The dependent variable was HDL level. The independent variables were variation dose of ethanol extract, Sechium edule (Jacq.) Swartz fraction and juice.

\section{Operational Definition of Variables} HDL level is the result of blood serum spectrophotometer examination using a diagnostic spectrum reagent.

\section{Study Instruments}

HDL examination was carried out in an integrated laboratory at the Faculty of Medicine, University of North Sumatra, using the Spectrophotometric method with spectrum diagnostic reagents.

\section{Data Analysis}

HDL levels after received ethanol extract, Sechium edule (Jacq.) Swartz fraction and juice were analyzed by using Anova test.

\section{RESULTS}

HDL levels were measured after 21 days of administering the extract, fraction and juice of Sechium edule (Jacq.) Swartz and compared with the control group as shown in Table 1.

From Table 1, it was found that the highest HLD content was found in group G which was given chayote fruit ethanol extract $150 \mathrm{mg} / \mathrm{kgBW}$ per oral, while the lowest HLD level was found in group $\mathrm{O}$ which was given chayote juice $100 \mathrm{mg} /$ KgBW per oral with <0.001, which means there is a meaningful relationship.

Table 1. HDL levels of Wistar male white rats (Rattus novergius sp.)

\begin{tabular}{cccc}
\hline \multirow{2}{*}{ Group } & Level of HDL & & p \\
\cline { 2 - 3 } & Mean & SD & 1.74 \\
2 & 18.13 & 8.08 \\
3 & 25.16 & 1.72 \\
4 & 14.41 & 2.20 \\
5 & 7.50 & 6.82 \\
6 & 10.50 & 2.09 & \\
7 & 9.70 & $\mathbf{3 . 1 4}$ & $<0.001$ \\
8 & $\mathbf{1 7 . 3 1}$ & 6.50 & \\
9 & 13.04 & 1.46 & \\
10 & 9.78 & 1.50 & \\
11 & 8.06 & 1.92 \\
12 & 6.24 & 2.40 & \\
13 & 7.46 & 1.02 & \\
14 & 7.18 & 1.54 \\
15 & 8.91 & $\mathbf{2 . 2 7}$ & \\
16 & $\mathbf{5 . 8 0}$ & 1.57 & \\
17 & 7.64 & 1.11 & \\
18 & 7.15 & 1.72
\end{tabular}

Note:

a. Group 1, negative control (normal) was not given any treatment, like normal rats in general who were given excessive food and drink (ad libitum) in their cages.

b. group 2, positive control, induced Streptozotocin $50 \mathrm{mg} / \mathrm{kgBW}+\mathrm{HFD}$

c. group 3, Positive control, induced nicotinamide (120 mg / kg) + HFD

d. group 4, Positive control, induced Streptozotocin $50 \mathrm{mg} / \mathrm{kgBW}+$ nicotinamide (120 mg / $\mathrm{kg})+\mathrm{HFD}$

e. group 5, the treatment group induced by Streptozotocin $50 \mathrm{mg} / \mathrm{kgBW}+$ nicotinamide (120 
mg / kg) + HFD, with ethanol extract of chayote fruit $50 \mathrm{mg} / \mathrm{kgBW}$, p.o.

f. group 6, the treatment group that was induced by Streptozotocin $50 \mathrm{mg} / \mathrm{kgBW}+$ nicotinamide (120 mg / kg) + HFD, with ethanol extract of chayote fruit $100 \mathrm{mg} / \mathrm{kgBW}$, p.o.

g. group 7, the treatment group which was induced by Streptozotocin $50 \mathrm{mg} / \mathrm{kgBW}+$ nicotinamide (120 mg / kg) + HFD, with ethanol extract of chayote fruit $150 \mathrm{mg} / \mathrm{kgBB}$, p.o.

h. group 8, the treatment group that was induced by Streptozotocin $50 \mathrm{mg} / \mathrm{kg}+$ nicotinamide $(120 \mathrm{mg} / \mathrm{kg})+\mathrm{HFD}$, with the ethyl acetate fraction of chayote $50 \mathrm{mg} / \mathrm{kg}, \mathrm{p} .0$.

i. group 9, the treatment group that was induced by Streptozotocin $50 \mathrm{mg} / \mathrm{kgBW}+$ nicotinamide (120 mg / kg) + HFD, with the ethyl acetate fraction of chayote $100 \mathrm{mg} / \mathrm{kgBB}$, p.o.

j. group 10, the treatment group that was induced by Streptozotocin $50 \mathrm{mg} / \mathrm{kgBW}+$ nicotinamide (120 mg / kg) + HFD, with the ethyl acetate fraction of chayote $150 \mathrm{mg} / \mathrm{kg}$, p.o.

k. group 11, the treatment group that was induced by Streptozotocin $50 \mathrm{mg} / \mathrm{kgBW}+$ nicotinamide (120 mg / kg) + HFD, with the $\mathrm{n}$ fraction of chayote's hexane $50 \mathrm{mg} / \mathrm{kgBB}$, p.o.

l. group 12, the treatment group that was induced by Streptozotocin $50 \mathrm{mg} / \mathrm{kgBW}+$ nicotinamide (120 mg / kg) + HFD, with fraction $\mathrm{n}$ hexane of chayote fruit $100 \mathrm{mg} / \mathrm{kgBW}$, p.o.

m. group 13, the treatment group that was induced by Streptozotocin $50 \mathrm{mg} / \mathrm{kgBW}+$ nicotinamide (120 mg / kg) + HFD, with $\mathrm{n}$ hexane fraction of chayote fruit $150 \mathrm{mg} / \mathrm{kg}$, p.o.

n. group 14, the treatment group that was induced by Streptozotocin $50 \mathrm{mg} / \mathrm{kgBW}+$ nicotinamide (120 mg / kg) + HFD, with chayote juice $50 \mathrm{mg} / \mathrm{KgBW}$ p.o

o. group 15, the treatment group that was induced by Streptozotocin $50 \mathrm{mg} / \mathrm{kgBW}+$ nicotinamide (120 mg / kg) + HFD, with chayote juice $100 \mathrm{mg} / \mathrm{KgBW}$ p.o

p. group 16, the treatment group that was induced by Streptozotocin $50 \mathrm{mg} / \mathrm{kgBW}+$ nicotinamide (120 mg / kg) + HFD, with chayote juice $150 \mathrm{mg} / \mathrm{KgBW}$ p.o

q. group 17, the treatment group that was induced by Streptozotocin $50 \mathrm{mg} / \mathrm{kg}+$ nicotinamide (120 mg / kg) + HFD, with metformin $500 \mathrm{mg} / \mathrm{KgBW}$ p.o

r. group 18, the treatment group that was induced by Streptozotocin $50 \mathrm{mg} / \mathrm{kg}+$ nicotinamide (120 mg / kg) + HFD, with simvastatin $500 \mathrm{mg} / \mathrm{KgBW}$ p.o

\section{DISCUSSION}

Hyperlipidemia is a common metabolic disorder that causes cardiovascular disease, where there is an increase in the concentration of fat or lipo protein which results in impaired fat metabolism. This is based on high carbohydrate intake, familial hypercholesterolemia (FH), obesity, and diabetes (Yao et al., 2020). In this study, it was shown that the chayote extracts $150 \mathrm{mg} /$ $\mathrm{kgBW}$ per oral was better at increasing HDL levels compared to the ethyl acetate fraction, $\mathrm{n}$ hexane fraction and juice. This is because the ethanol solvent is able to attract bioactive compounds in the extract, both polar and non-polar (Saleh, 2016), while the n-hexane solvent is non-polar and ethyl acetate is semipolar so that a more specific fraction attracts bioactive com- pounds according to the polarity of the solvent (Da'i et al., 2020). Chayote extract using ethanol solvent contains alkaloids, flavonoids, glycosides, sapaonins, tannins and triperten (Siahaan, 2020). This study is in line with Neeraja et al. (2015), that the ethanol extract $200 \mathrm{mg} / \mathrm{KgBW}$ can significantly increase HDL.

Bioactive flavonoid compounds can reduce cholesterol levels through cholesterol synthetase inhibition, LDL receptor expression, cholesterol acyltransferase-1 (ACAT-1), cholesterol acyltransferase-2 (ACAT-2), MTP (microsomal triglyceride transfer protein). In addition, flavonoids work as antiatherogenic by inhibiting hepatic acyl CoA: cholesterol acyltransferase (ACAT), reducing cholesterol absorption and the expression of VCAM-1 (vascular cell 
adhesion molecule-1) and MCP-1 (monocyte chemoattractant protein-1) which plays an important role in adhesion. monocytes in the endothelium of blood vessels (Zeka et al., 2017).

Tannin bioactive compounds can reduce lipid metabolism by inhibiting lipase performance thereby reducing muscle fat accumulation (Yao et al., 2019). Tannins also affect fatty acid catabolism in the liver by controlling lipoprotein hydrolysis and fat absorption (Ravichandiran et al., 2012). In HepG2 cells, tannins inhibit the accumulation of TG and cholesterol (Oh et al., 2018)

Saponin bioactive compounds have an effect in inhibiting pancreatic lipase, controlling body weight by inhibiting adipogenesis, controlling appetite (Marrelli et al., 2016). In broilers, sapaonin has the effect of inhibiting the expression of HMG-CoA reductase mRNA in the liver, accelerating the excretion of bile acids through feces and reducing hepatic cholesterol synthesis (Liu et al, 2016).

Alkaloid bioactive compounds also have a role in the activation of the enzyme lecithin cholesterol acyltransferase (LCAT) which inhibits cholesterol biosynthesis and plays an important role in the cholesterol transfer pathway when cells are unable to metabolize cholesterol. With the LCAT enzyme, HDL works more effectively to stimulate the flow of cholesterol from cells to receptors in the liver (Said et al, 2018).

From the results of this study it can be concluded that the ethanol extract $150 \mathrm{mg}$ / $\mathrm{kgBW}$ per oral is better to increase HDL, because ethanol solvent contains more complex bioactive compounds.

\section{AUTHOR CONTRIBUTION}

Jekson Martiar Siahaan, Endy Julianto and Tengku Muhammad Fauzi are those who carry out sample preparation, spectro- photometric examination, data interpretation and article preparation.

\section{CONFLICT OF INTEREST}

There is no conflict of interest in this study.

FUNDING AND SPONSORSHIP

This research is fully funded by DRPM DIKTI Beginner Lecturer Research Grant (PDP) for the 2019-2020 fiscal year.

\section{ACKNOWLEDGEMENT}

We would like to thank DRPM DIKTI, LLDIKTI region 1, LP3M Indonesian Methodist University for giving researchers the opportunity to take part in the Competitive Grants for Beginner Lecturer Research (PDP) twice in a row.

\section{REFERENCE}

Barter PJ (2011).The causes and consequences of low levels of high density lipoproteins in patients with diabetes. Diabetes Metab J. 35(2): 101-106. https://dx.doi.org/10.4093\%2Fdmj.2011.35.2.101.

Farbstein D, Levy AP (2012). HDL dysfunction in diabetes: causes and possible treatments. Expert Rev Cardiovasc Ther. 10(3): 353-361. https://doi.org/10.1586/erc.11.182

Hirano T (2018). Pathophysiology of diabetic dyslipidemia. $\mathrm{J}$ Atheroscler Thromb. 25(9): 771-782. https://doi.org/10.5551/jat.rv17023.

Poznyak A, Grecho AV, Poggio P, Myasoedova VA, Alfieri V, Orekhov AN (2020). The diabetes mellitus-atherosclerosis connection: The role of lipid and glucose metabolism and chronic inflammation. Int $\mathrm{J}$ Mol Sci. 21(5):1835. https://doi.org/10.3390/ijms21051835.

Younis NN, Durrington PN (2012). HDL functionality in diabetes mellitus: 
potential importance of glycation. Clinical Lipidology. 7(5): 561-578. https://doi.org/10.2217/clp.12.60.

Femlak M, Gluba-Brzózka A, CiałkowskaRysz A, Rysz J (2017). The role and function of HDL in patients with diabetes mellitus and the related cardiovascular risk. Lipids Health Dis. 16(1): 207. https://doi.org/10.1186/s12944017-0594-3.

Bjornstad P, Eckel RH (2018). Pathogenesis of lipid disorders in insulin resistance: A brief review. Curr Diab Rep. 18(12): 127. https://doi.org/10.1007/s11892018-1101-6.

Tavori H, Rosenblat M, Vaya J, Aviram M (2010). Paraoxonase 1 interactions with atherosclerotic lesions and arterial macrophages protect against foam cell formation and atherosclerosis development. Clin Lipidology. 5: 5, 685-697. https://doi.org/10.2217/clp.10 .57 .

Millar CL, Duclos Q, Blesso CN (2017). Effects of dietary flavonoids on reverse cholesterol transport, HDL metabolism, and HDL function. Adv Nutr. 8(2): 226-239. https://doi.org/10.3945/an.116.014050.

Siahaan JM, Julianto E, Silitonga HA (2019).The effects of ethanol extract and ethyl acetatefractionation of Sechium Edule Jacq. Swartz on triglyceride levelsin male rats with type 2 diabetes mellitus. Indones $\mathrm{J}$ Med. 4(4): 371-375. https://doi.org/10.26911/theijmed.2019.04.04.10.

Wu CH, Ou TT, Chang CH, Chang XZ, Yang MY, Wang CJ (2014). The polyphenol extract from sechium edule shoots inhibits lipogenesis and stimulates lipolysis via activation of AMPK signals in HepG2 Cells. J Agric Food Chem. 62(3): 750-759. https://doi.org/10.1021/jf404611a.
Neeraja K, Debnath R, Firdous S (2015). Cardioprotective activity of fruits of Sechium edule. Bangladesh J Pharmacol. 10(1): 125-130. https://doi.org/10.3329/bjp.v10i1.21329.

Vieira EF, Pinho O, Ferreira IMPLVO, Delerue-Matos C (2018). Chayote (Sechium edule): A review of nutritional composition, bioactivities and potential applications. Food Chemistry. 275: 557-568. https://doi.org/10.1016/j.foodchem.2018.09.146.

Yao YS, Li TD, Zeng ZH (2020). Mechanisms underlying direct actions of hyperlipidemia on myocardium: An updated review. Lipids Health Dis. 19(1): 23. https://doi.org/10.1186/s12944-019-1171-8.

Saleh FR (2016). Antibacterial activity of seeds of Iraqi dates. J Bio Innov. 5(2): 313-318.https://www.jbino.com/docs/Issue02_17_2016.pdf.

Da'i M, Wardani RZ, Saifudin A (2020). Isolation and identification of active antioxidant compounds from ethyl acetate fraction of ethanol extract of meniran herb (Phyllantus Niruri L.). EurAsian Journal of BioSciences. 14: 5461-5467.

Siahaan JM (2020). Impressi ekstrak etanol buah labu siam: Tinjauan kritis ekstrak etanol buah labu siam dan stress oksidatif tikus putih model diabetes tipe 2. Tasikmalaya: Edu Publisher.

Zeka K, Ruparelia K, Arroo RRJ, Budresi R, Micucci M (2017). Flavonoids and their metabolites: Prevention in cardiovascular diseases and diabetes. Diseases. 5(3):19. https://doi.org/10.3390/diseases5030019.

Yao J, Chen P, Apraku A, Zhang G, huang $Z$, hua X (2019). Hydrolysable tannin supplementation alters digestibility and utilization of dietary protein, 
lipid, and carbohydrate in grass carp (Ctenopharyngodon idellus). Front Nutr. 6: 183. https://doi.org/10.3389/fnut.2019.00183.

Velayutham R, Sankaradoss N, Ahamed KFHN (2012). Protective effect of tannins from Ficus racemosa in hypercholesterolemia and diabetes induced vascular tissue damage in rats. Asian Pac J Trop Med. 5(5):367-73. https://doi.org/10.1016/s1995-7645(12)6o061-3.

Oh EK, Ahn Y, Kwon O (2018). Persimmon tannin regulates gene expressions important for lipogenesis and cholesterol efflux in HepG2 cells. The Federation of American Societies for Experimental Biology (FASEB).31(1): 218. https://doi.org/10.1096/fasebj.31.1_supplement.lb218.

Marrelli M, Conforti F, Araniti F, Statti GA (2016). Effects of saponins on lipid metabolism: A review of potential health benefits in the treatmentof obesity. Molecules. 21(1)): 1404. https://doi.org/10.3390/molecules21101404.

Liu T, Li Z, Wang T, Zhu X (2016). Effects of alfalfa saponins on cholesterol metabolism in broilers. J Nutr Food Sci. 6: 546. doi: 10.4172/2155-9600.1000546.

Kata FS, Athbi AM, Manwar EQ, Al-Ashoor A, Abdel-Daim MM, Aleya L (2018). Therapeutic effect of the alkaloid extract of the cyanobacterium Spirulina platensis on the lipid profile of hypercholesterolemic male rabbits. Environ Sci Pollut Res. 25(20): 19635-19642. https://doi.org/10.1007/s11356-018-2170-4. 